\title{
Responses of Whitefly and Poinsettias to Insecticidal Controlled Atmospheres
}

\author{
Susan S. Han ${ }^{1}$ and Jennifer Konieczny \\ Department of Plant and Soil Sciences, French Hall, University of Massachusetts, Amherst, MA 01003-2910
}

\begin{abstract}
ADDITIONAL INDEX WORDs. Trialeurodes vaporarium, Bemisia argentifolii, Euphorbia pulcherrima, reduced- $\mathrm{O}_{2}$ atmospheres, elevated- $\mathrm{CO}_{2}$ atmospheres

Abstract. Eggs, larvae, pupae, and adult stages of greenhouse whitefly (Trialeurodes vaporarium Westwood) and silverleaf whitefly (Bemisia argentifolii Bellows \& Perring) were exposed to insecticidal controlled atmospheres at $20^{\circ} \mathrm{C}$ or $30{ }^{\circ} \mathrm{C}$. Mortality data were calculated for each stage and results demonstrated that reduced- $\mathrm{O}_{2}$ atmospheres $\left(\right.$ an $\mathrm{O}_{2}$ level of $<2$ $\mu \mathrm{L} \cdot \mathrm{L}^{-1}$ balance in $\left.\mathrm{N}_{2}\right)$ resulted in faster and higher mortality than elevated- $\mathrm{CO}_{2}$ atmospheres $\left(25 \%\right.$ or $\left.50 \% \mathrm{CO}_{2}\right)$. Responses, from the least to most tolerant stage was adult < larvae < eggs = pupae, regardless of the species of whitefly and treatment temperature. At $20^{\circ} \mathrm{C}$, treatment time required to kill >90\% of adults, larvae, and eggs and pupae was 2, 4, and 8 hours, respectively. Increasing the treatment temperature from 20 to $30{ }^{\circ} \mathrm{C}$ reduced the treatment time to one-half that of $20^{\circ} \mathrm{C}$. Treatment time required to achieve complete elimination of the insects also caused phytotoxicity symptoms on poinsettias (Euphorbia pulcherrima Willd. ex Klotzsch), thus, limiting use of insecticidal controlled atmospheres as the sole means for managing whitefly.
\end{abstract}

Infestation of poinsettia (Euphorbia pulcherrima) with greenhouse whitefly (Trialeurodes vaporarium) and silverleaf whitefly (Bemisia argentifolii) can cause major economic losses of this leading floricultural crop. Although there are pesticides that effectively control this insect, restrictions on the amount and type of pesticide used in greenhouses have forced the industry to examine other methods for control of pests.

Controlled atmosphere (CA) is an alternative method for controlling insects. Insecticidal controlled atmospheres are those which are lethal to insects as a result of alteration of surrounding air, usually through application of high $\mathrm{CO}_{2}$ or low $\mathrm{O}_{2}$. Elevated $\mathrm{CO}_{2}(>50 \%)$ or reduced $\mathrm{O}_{2}(<1 \%)$ treatments have been investigated largely for postharvest insect control in long-term storage areas or for quarantine treatment of some edible crops. CA treatments are effective on various commodities for controlling insects such as the Caribbean fruit fly (Anastrepha suspensa Loew) (Benschoter, 1987), codling moth (Cydia pomonella L.) (Soderstrom and Brandl, 1987), and San Jose scale (Quadras-pidiotus perniciosus Comstock) (Chu, 1992), and the treatments have been suggested as a potential quarantine treatment for imported edible crops (Ke and Kader, 1991). The time required to cause $100 \%$ mortality depends on the particular species and developmental stage of the insect as well as the temperature and atmospheric composition during the treatment.

Commodities differ in their tolerance of insecticidal controlled atmospheres (Ke and Kader, 1991). High $\mathrm{CO}_{2}$ or reduced $\mathrm{O}_{2}$ may retard ripening and degradation of chlorophyll, and reduce chilling injury. Prolonged exposure of edible crops to CA frequently causes anaerobic respiration and thus the accumulation of ethanol, acetaldehyde, and other volatile compounds in the tissue which, in turn, may result in an off-flavor of the fruit (Davis and Chace, 1969; Norman and Croft, 1971; Pesis and Avissar, 1989). In contrast to the bulky anatomy of most edible crops, the higher surface to volume ratio of floricultural crops may increase the tolerance of CA (Joyce and Reid, 1985). Vase life of cut anthuriums (Anthuriumandraeanum

Received for publication 15 July 1999 . Accepted for publication 21 Feb. 2000. We thank the USDA Special Research Grant Center for Agricultural Management Research and the American Floral Endowment for partially funding this project. The cost of publishing this paper was defrayed in part by the payment of page charges. Under postal regulations, this paper therefore must be hereby marked advertisement solely to indicate this fact.

${ }^{1}$ Associate professor; to whom reprint requests should be addressed.
Lind.) (Akamine and Goo, 1981), carnations (Dianthus caryophyllus L.) (Hanan, 1967), daffodils (Narcissus pseudonarcissus L.) (Parsons et al., 1967), gladiolus (Gladiolus $\times$ hortulanus L.), roses (Rosa L. sp.), and snapdragons (Antirrhinum majus L.) (Thornton, 1930) has been extended by various combinations of CA treatments. Thus, the objectives of this research were to test the effectiveness of insecticidal controlled atmospheres for control of whitefly on poinsettias and to evaluate the effects of the treatments on poinsettia.

\section{Materials and Methods}

\section{Effects of reduced oxygen controlled atmospheres on whiteflies}

Adult whitefliEs. Adult greenhouse or silverleaf whiteflies from a rearing room at the University of Massachusetts, Amherst, were aspirated into $25 \times 150 \mathrm{~mm}$ tubes, placed in a $20^{\circ} \mathrm{C}$ controlled environment chamber (model 818; Precision Scientific, Inc., Chicago) and connected to a gas stream that delivered air (control) or a reduced $\mathrm{O}_{2}$ atmosphere $\left(\right.$ an $\mathrm{O}_{2}$ level of $100 \mu \mathrm{L} \cdot \mathrm{L}^{-1}$ or $<2 \mu \mathrm{L} \cdot \mathrm{L}^{-1}$ balance in $\mathrm{N}_{2}$ ) at a rate of $1 \mathrm{~L} \cdot \mathrm{h}^{-1}$. There were three replicate tubes per treatment with $\approx 100$ adults per tube. At the end of each treatment time $(0,0.5,1$, or $2 \mathrm{~h})$, tubes were connected immediately to the air stream. At various time intervals after the end of each treatment, live whiteflies (observed to have some movement) were counted. After $24 \mathrm{~h}$, dead insects were removed from the tubes and counted and remaining live whiteflies were gassed with alcohol vapors and counted to determine the total number of whiteflies in each tube at the start of the experiment. Percent mortality was calculated for each tube.

ImMATURE WhITEFLIES. Individual leaves with either the egg, larval, or pupal stage of greenhouse or silverleaf whiteflies were collected from infested poinsettia plants. The particular stage was circled on the leaves. Leaves were then placed in $20 \mathrm{~mL}$ vials containing water and treated with a constant flow of air or $\mathrm{N}_{2}$ (containing an an $\mathrm{O}_{2}$ level of $<2 \mu \mathrm{L} \cdot \mathrm{L}^{-1}$ balance in $\mathrm{N}_{2}$ for larvae and pupae and an $\mathrm{O}_{2}$ level of $\left\langle 2 \mu \mathrm{L} \cdot \mathrm{L}^{-1}\right.$ or $100 \mu \mathrm{L} \cdot \mathrm{L}^{-1}$ balance in $\mathrm{N}_{2}$ for eggs) in the controlled environment chamber as described previously. Following the gas treatments, leaves were maintained in a 20 ${ }^{\circ} \mathrm{C}$ growth chamber with a $16 \mathrm{~h}$ photoperiod $\left[17 \pm 3 \mu \mathrm{mol} \cdot \mathrm{m}^{-2} \cdot \mathrm{s}^{-1}\right.$ measured by a quantum sensor (LI-190SA; LI-COR, Lincoln, Neb.) at leaf level] provided by cool-white fluorescent lamps. Insects at the 
Fig. 1 (right). Percent mortality of adult greenhouse whitefly (Trialeurodes vaporarium) treated with reduced $\mathrm{O}_{2}$ levels $\left(<2 \mu \mathrm{L} \cdot \mathrm{L}^{-1}\right)$ for $0,0.5,1$ or $2 \mathrm{~h}$. Data were collected between 5 and $24 \mathrm{~h}$ after treatment. Data are means \pm SE. SE bars smaller than the symbols are not shown.
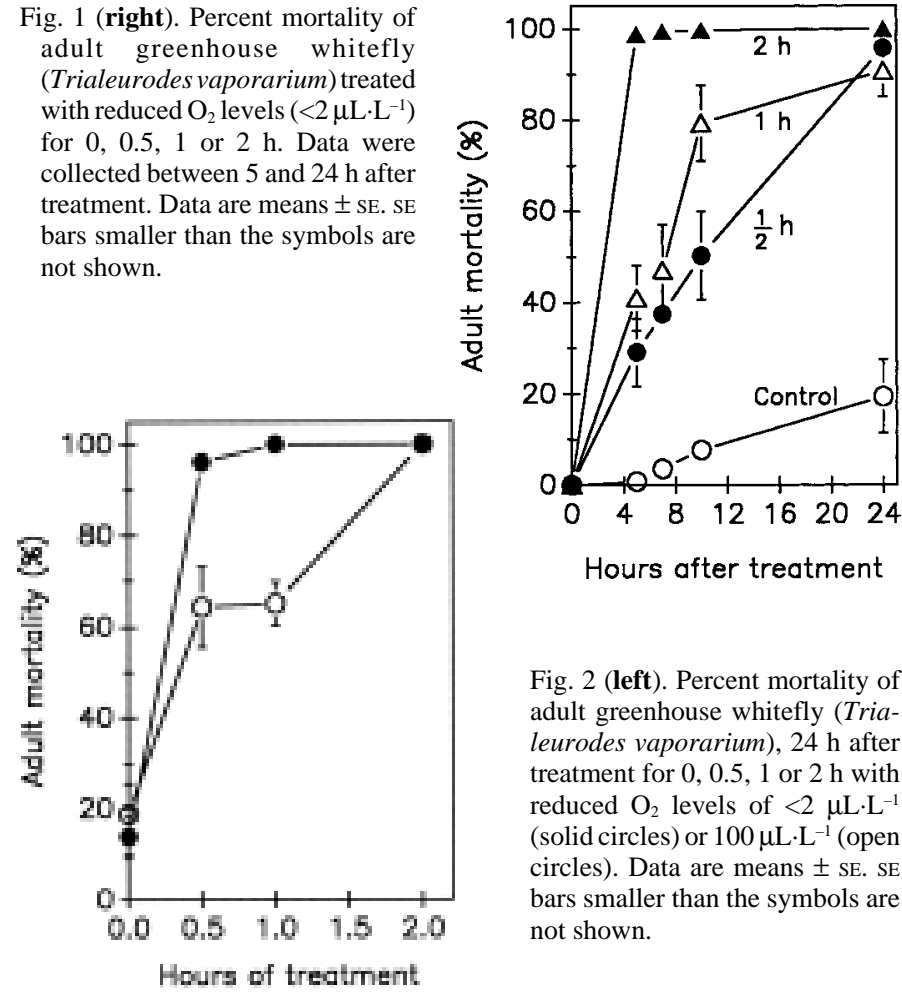

Fig. 2 (left). Percent mortality of adult greenhouse whitefly (Trialeurodes vaporarium), $24 \mathrm{~h}$ after treatment for $0,0.5,1$ or $2 \mathrm{~h}$ with reduced $\mathrm{O}_{2}$ levels of $<2 \mu \mathrm{L} \cdot \mathrm{L}^{-1}$ (solid circles) or $100 \mu \mathrm{L} \cdot \mathrm{L}^{-1}$ (open circles). Data are means \pm SE. SE bars smaller than the symbols are not shown.

designated stages of development within the circled areas were counted weekly. The survival rate at each stage was calculated following the passage of sufficient time for the development of insects into the next stage. Eggs were evaluated as percent hatched, larvae as percent killed, and pupae as percent emerged into adults. Data on percent of pupae that emerged successfully into adults were obtained by examination of the pupal cases under a stereoscopic microscope. Pupae that have emerged into adults leave a distinctive opening in the case whereas the cases of those that do not emerge remain intact. In addition, at times, the dead adults were observed in various stages of emergence from the pupal case.

TEMPERATURE. Silverleaf whiteflies at the egg, larval, and pupal stages were exposed to air or $\mathrm{N}_{2}$ (containing $\mathrm{O}_{2}$ at $<2 \mu \mathrm{L} \cdot \mathrm{L}^{-1}$ ) for 0 , 4 or $8 \mathrm{~h}$ at $20^{\circ} \mathrm{C}$, or for 0,2 , or $4 \mathrm{~h}$ at $30^{\circ} \mathrm{C}$, using the methods described above.

\section{Effects of elevated $\mathrm{CO}_{2}$ controlled atmospheres on whiteflies}

Greenhouse whiteflies were treated with a constant flow of $25 \%$ or $50 \% \mathrm{CO}_{2}$ for 0 to $8 \mathrm{~h}$ for the adult stage and for 0 to $24 \mathrm{~h}$ for eggs and pupae. Percent mortality of adult whiteflies and the survival rate of eggs and pupae were calculated as described previously.

\section{Tolerance of poinsettias to insecticidal controlled atmo- spheres}

ROOTED STEM CUTTINGS. Rooted stem cuttings of nine cultivars of poinsettia ('Celebrate', 'Annette Hegg Red', 'Freedom Red', 'Lilo Red', 'Pink Peppermint', 'Red Sails', 'Supjibi Red', 'V-14 Glory', and 'V-17 Angelica') were obtained from Paul Ecke Ranch, Encinitas, Calif. Six cuttings of each cultivar were placed in 30-L glass tanks housed in a $20{ }^{\circ} \mathrm{C}$ dark chamber and vented with a constant flow $\left(45 \mathrm{~L} \cdot \mathrm{h}^{-1}\right.$ ) of air or $\mathrm{N}_{2}$ (containing $\mathrm{O}_{2}$ at $<2 \mu \mathrm{L} \cdot \mathrm{L}^{-1}$ ) for $8 \mathrm{~h}$. Cuttings were then transplanted into $10-\mathrm{cm}(450-\mathrm{mL})$ pots filled with a peat based medium (ProMix BX; Premier Brands Inc., Stamford, Conn.) and grown in a glasshouse at the University of Massachusetts, Amherst (lat. $42^{\circ} 22.5^{\circ} \mathrm{N}$ ) at day/nights of $19 / 17^{\circ} \mathrm{C}$ (day/night) and under $8 \mathrm{~h}$ of natural light with a night interruption from $10 \mathrm{PM}$ to $2 \mathrm{AM}$ of $3.6 \mu \mathrm{mol} \cdot \mathrm{m}^{-2} \cdot \mathrm{s}^{-1}$ provided by incandescent bulbs. Plants werefertilized with $20 \mathrm{~N}-4.3 \mathrm{P}-16.6 \mathrm{~K}$ at $200 \mathrm{Nmg} \cdot \mathrm{L}^{-1}$. Phytotoxicity, based on signs of physiological disorders such as discoloration, wilting, and constricted petioles, was recorded on the day after the termination of the treatment and at weekly intervals for 3 weeks. The degree of phytotoxicity was estimated visually, at $10 \%$ increments, as the percentage of total bract area with discoloration. Plant height and dry weight of the stems and leaves were determined 4 weeks after planting, and data were subjected to analysis of variance procedures (SAS Institute Inc., 1990). Paired comparisons were used to test for differences between the nontreated (control) and treated plants.

Flowering Plants. To explore the possibility of using controlled atmosphere as a quarantine treatment for saleable plants, rooted stem cuttings of six cultivars of poinsettias ('Celebrate II', 'Freedom Red', 'V-14 Glory', 'Annette Hegg Red', 'Pink Peppermint', and 'Supjibi') from Paul Ecke range were potted up and grown until anthesis in the University of Massachusetts glasshouse. Cultural conditions (light, temperature, and fertilization) were the same as those described previously. Flowering plants were treated for $8 \mathrm{~h}$ with air or $\mathrm{N}_{2}$ (containing $\mathrm{O}_{2}$ at $<2 \mu \mathrm{L} \cdot \mathrm{L}^{-1}$ ) in a dark, $20^{\circ} \mathrm{C}$ chamber. Following treatment, plants were transferred back to the greenhouse and the appearance of phytotoxicity was recorded $2 \mathrm{~d}$ after treatment.

\section{Results}

\section{Effects of reduced oxygen CA on greenhouse whiteflies}

EFFECTS ON ADULTS. Exposure of adult greenhouse whiteflies to an $\mathrm{O}_{2}$ atmosphere of $100 \mu \mathrm{L} \cdot \mathrm{L}^{-1}$ for $2 \mathrm{~h}$ resulted in $100 \%$ mortality within $24 \mathrm{~h}$ of treatment, whereas a briefer exposure for 0.5 or $1 \mathrm{~h}$ at an $\mathrm{O}_{2}$ atmosphere $<2 \mu \mathrm{L} \cdot \mathrm{L}^{-1}$ resulted in $>90 \%$ mortality (Fig. 1). Percent mortality was reduced to $65 \%$ when adults were treated with an $\mathrm{O}_{2}$ atmosphere of $100 \mu \mathrm{L} \cdot \mathrm{L}^{-1}$ for $<2 \mathrm{~h}$ (Fig. 2).

EFFECTS ON EGGS. An $8 \mathrm{~h}$ treatment with $\mathrm{O}_{2}$ at $100 \mu \mathrm{L} \cdot \mathrm{L}^{-1} \mathrm{did}$ not consistently prevent eggs from hatching (data not presented), whereas an 8-h treatment with an $\mathrm{O}_{2}$ level of $<2 \mu \mathrm{L} \cdot \mathrm{L}^{-1}$ significantly reduced egg hatch (Fig. 3B). Percent hatch collected 2 weeks after an 8 -h treatment with low- $\mathrm{O}_{2}\left(<2 \mu \mathrm{L} \cdot \mathrm{L}^{-1}\right)$ or air was $8.2 \%$ and $100 \%$, respectively. In subsequent experiments, eggs at different stages of development were treated with low $\mathrm{O}_{2}$. The stages were defined based on the color change of the eggs from white to dark gray (Sanderson and Ferrentino, 1989). Percent hatch of white (earlier stage) and black (later stage) eggs was collected individually. One week after treatment, percent hatch of eggs treated with air was less for white versus dark colored eggs, reflecting differences in developmental stages of the eggs at the time of treatment (Fig. 4). By the second week, however, all of the white and dark colored eggs treated with air hatched. In contrast, there were no differences in percent hatch of white and dark eggs treated with low $\mathrm{O}_{2}$. Only $10 \%$ of the eggs treated with low $\mathrm{O}_{2}$ hatched, regardless of the stage of development, indicating that the response of eggs to the reduced $\mathrm{O}_{2}$ treatment is independent of their developmental stage.

EFfects on LaRvaE. All larval stages of greenhouse whitefly (crawler through fourths) were highly susceptible to exposure to low $\mathrm{O}_{2}\left(<2 \mu \mathrm{L} \cdot \mathrm{L}^{-1}\right)$ (Fig. 3C). Treatment for 4 or $8 \mathrm{~h}$ resulted in dehydration and death of larvae within a few days. Percent mortality of larvae treated with 4 or $8 \mathrm{~h}$ of $\mathrm{O}_{2}$ at $<2 \mu \mathrm{L} \cdot \mathrm{L}^{-1}$ was $>90 \% 1$ week after treatment, and was $\approx 100 \%$ a week later. 



Fig. 3. Effects of low- $\mathrm{O}_{2}\left(<2 \mu \mathrm{L} \cdot \mathrm{L}^{-1}\right)$ treatment on (A) percent mortality of adults, $24 \mathrm{~h}$ after treatment, (B) hatch of eggs, (C) nymph mortality, and (D) emergence of pupae of greenhouse whitefly (Trialeurodes vaporarium). Survival rate of the immature stages of whitefly was calculated following the passage of sufficient time for the development of insects into the next stage. Data are means \pm SE. SE bars smaller than the symbols are not shown.

Fig. 4. Percent hatch of two stages of greenhouse whitefly (Trialeurodes vaporarium) eggs at (A) early (white) and (B) late (black) stage treated with air (circles) or low- $\mathrm{O}_{2}$ treatment (triangles) $\left(<2 \mu \mathrm{L} \cdot \mathrm{L}^{-1}\right)$ for $8 \mathrm{~h}$. Data are means \pm SE. SE bars smaller than the symbols are not shown.

EFFECTS ON PUPAE. Exposure of whitefly pupae to $\mathrm{O}_{2}$ at $<2 \mu \mathrm{L} \cdot \mathrm{L}^{-1}$ for $4 \mathrm{~h}$ decreased percent emergence to $\approx 40 \%, 2$ weeks after treatment, in comparison to almost $100 \%$ emergence for controls (Fig. 3D).

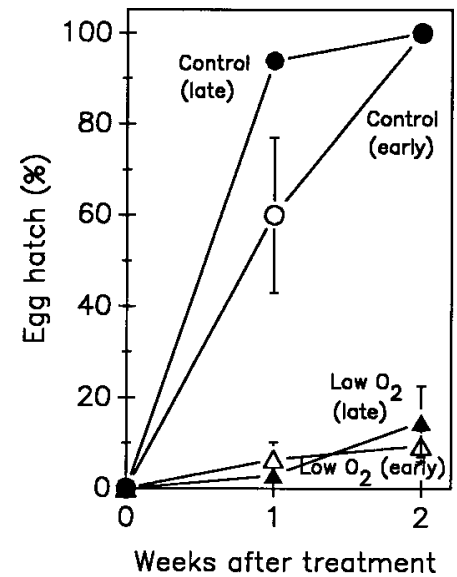
Only $6 \%$ of those treated for 8 h emerged within 2 weeks after treatment. The $\mathrm{O}_{2}$ atmosphere of $100 \mu \mathrm{L} \cdot \mathrm{L}^{-1}$ did not reduce emergence of pupae (data not presented).

\section{Effects of insecticidal controlled atmospheres on silverleaf whitefly}

RESPONSES OF SILVERLEAF WHITEFLY TO REDUCED OXYGEN ATMOSPHERES. In general, responses of silverleaf whitefly (Fig. 5) to the CA treatment are similar to those of greenhouse whitefly (Fig. 3 ). In both species, the adult stage was most sensitive to the CA treatment with $100 \%$ mortality occurring after an exposure time of $<2 \mathrm{~h}$ at $20^{\circ} \mathrm{C}$. In contrast, eggs were most resistant to the treatment. After a 4 or $8 \mathrm{~h}$ treatment with $\mathrm{O}_{2}<2 \mu \mathrm{L} \cdot \mathrm{L}^{-1}, 10 \%$ and $80 \%$, respectively, of the eggs failed to hatch. The larval stage of greenhouse whitefly was killed by a 4-h treatment (Fig. 3C) while sufficient control of silverleaf whitefly required $8 \mathrm{~h}$ (Fig. 5C). An $8 \mathrm{~h}$ exposure was required to kill $>80 \%$ of the pupae.

EFFECTS OF TEMPERATURE ON MORTALITY RATE. Increasing treatment temperature, from 20 to $30^{\circ} \mathrm{C}$, significantly decreased the required CA treatment time (Fig. 6). Except for adult whiteflies, treatment times at $30^{\circ} \mathrm{C}$ were usually half of those at $20^{\circ} \mathrm{C}$ to achieve the same rate of mortality.

\section{Effects of elevated $\mathrm{CO}_{2}$ atmosphere on whiteflies}

An 8-h treatment with $25 \%$ or $50 \% \mathrm{CO}_{2}$ was effective at killing adult greenhouse and silverleaf whiteflies but was not effective on immature stages. Increasing the treatment time to $24 \mathrm{~h}$ still did not successfully control the pupae: $60 \%$ of the pupae emerged after treatment for $24 \mathrm{~h}$ with $25 \% \mathrm{CO}_{2}$ compared to $90 \%$ of that emerged after the air (control) treatment. Further testing (increased concentrations or duration) of the effects of elevated $\mathrm{CO}_{2}$ was discontinued because certain cultivars of poinsettia cuttings treated with $24 \mathrm{~h}$ of the $\mathrm{CO}_{2} \mathrm{CA}$ developed phytotoxicity, thus, limiting practical application of the treatment. At the termination of $\mathrm{CO}_{2}$ treatment, there were no signs of damage on the plants.
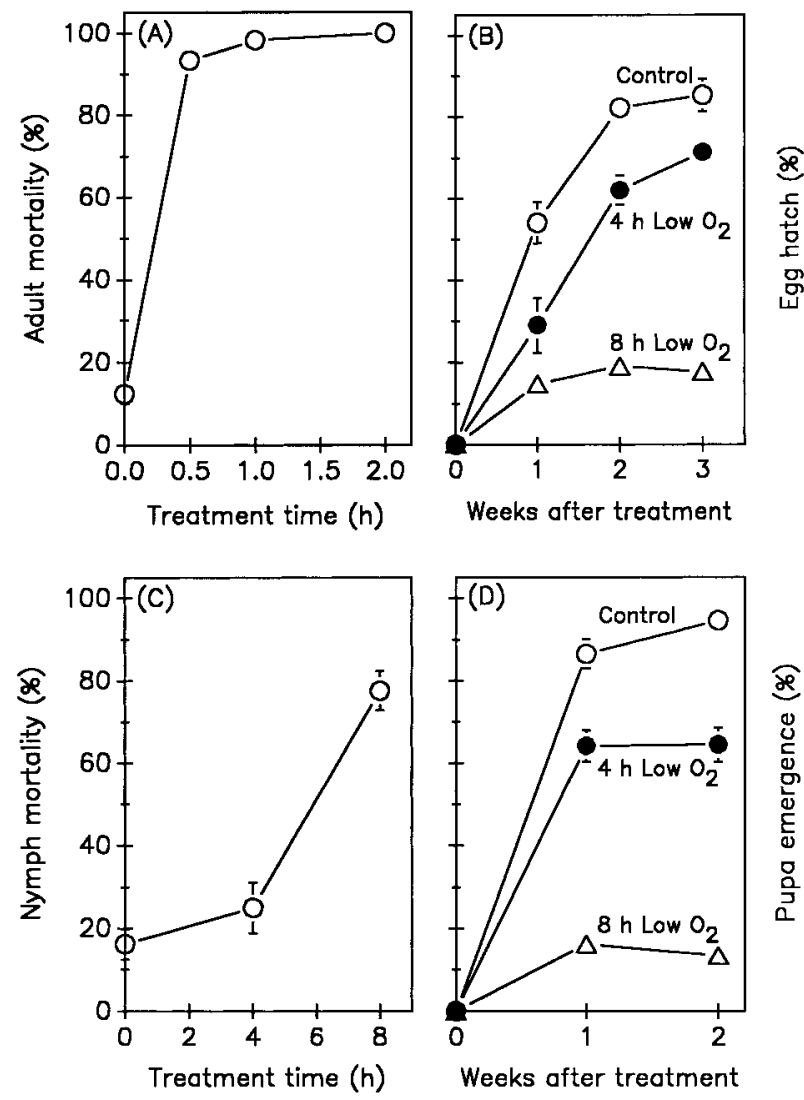

Fig. 5. Effects of low- $\mathrm{O}_{2}$ treatment $\left(<2 \mu \mathrm{L} \cdot \mathrm{L}^{-1}\right)$, applied at $20^{\circ} \mathrm{C}$, on (A) percent mortality of adults, (B) hatch of eggs, (C) nymph mortality, and (D) emergence of pupae of silverleaf whitefly (Bemisia argentifolii). The mortality rate of adults was collected $24 \mathrm{~h}$ after treatment and the survival rate of the immature stages was calculated following the passage of sufficient time for development of insects into the next stage. Data are means \pm SE. SE bars smaller than the symbols are not shown. 

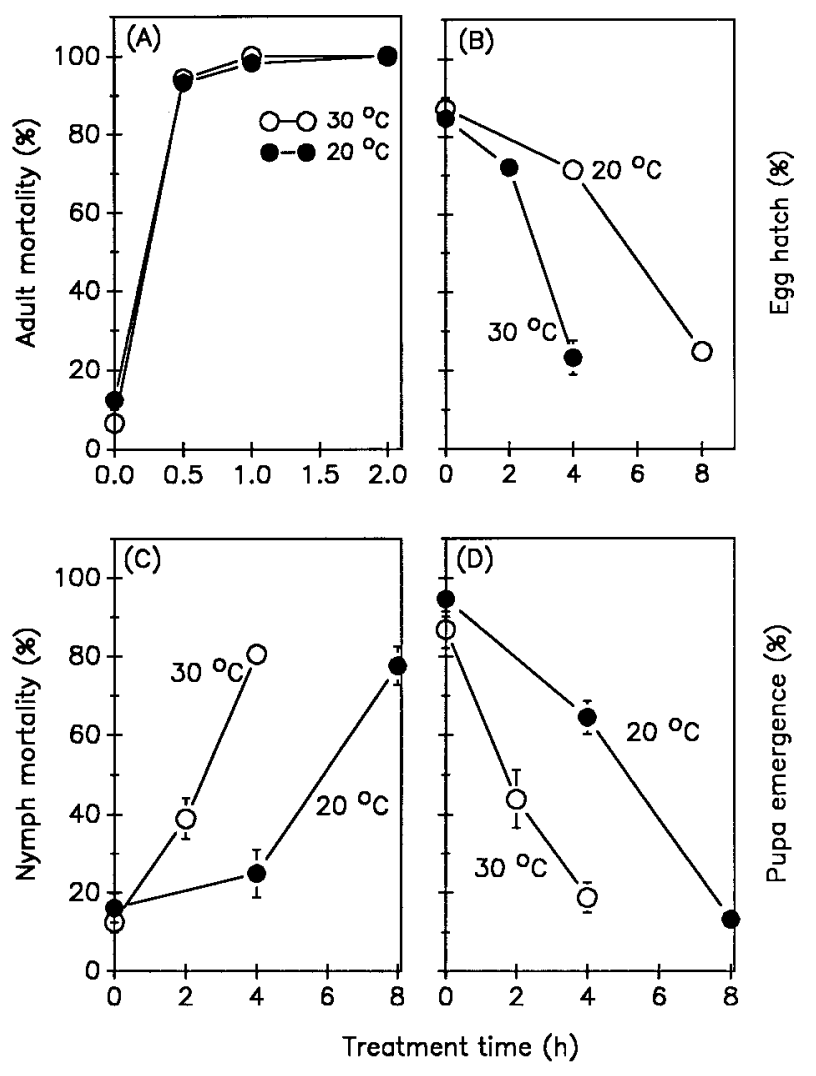

Fig. 6. Effects of low- $\mathrm{O}_{2}$ treatment $\left(<2 \mu \mathrm{L} \cdot \mathrm{L}^{-1}\right)$, at $30^{\circ} \mathrm{C}$ or $20^{\circ} \mathrm{C}$, on the mortality of (A) percent mortality of adults, (B) hatch of eggs, (C) nymph mortality, and (D) emergence of pupae of silverleaf whitefly (Bemisia argentifolii). The mortality rate of adults was collected $24 \mathrm{~h}$ after the treatment and the survival rate of the immature stages was calculated following the passage of sufficient time for the development of insects into the next stage. Data are means \pm SE. SE bars smaller than the symbols are not shown.

However, plants were less turgid (wilted leaves) $12 \mathrm{~h}$ after treatment. Within $24 \mathrm{~h}$ after treatment, phytotoxicity symptoms such as necrotic areas on the margins of the bracts, upward curling of the margin of the bracts, and collapsed petioles and stems, were observed.

\section{Effects of insecticidal controlled atmospheres on poinset- tias}

Rooted CUTTINGs. During vegetative growth, no phytotoxic- ity was observed on any of the nine poinsettia cultivars after exposure of rooted cuttings to $\mathrm{O}_{2}$ at $<2 \mu \mathrm{L} \cdot \mathrm{L}^{-1}$ for $8 \mathrm{~h}$. Growth was affected only in the cultivars Supjibi Red and V-17 Angelica where treated plants were shorter and had lower dry weights than the controls (Table 1).

FLOWERING PLANTS. Within $2 \mathrm{~d}$ after flowering poinsettias were exposed to $\mathrm{O}_{2}$ at $<2 \mu \mathrm{L} \cdot \mathrm{L}^{-1}$ for $8 \mathrm{~h}$, the cultivars Annette Hegg Red and Freedom Red developed phytotoxicity symptoms, evident as areas of discoloration and necrosis, on the bracts (Table 2). Significantly less phytotoxicity occurred on the other cultivars.

\section{Discussion}

Insecticidal controlled atmospheres can effectively control whitefly. Reduced $\mathrm{O}_{2}$ atmospheres, delivered from $\mathrm{N}_{2}$ cylinders (containing $\mathrm{O}_{2}$ at $<2 \mu \mathrm{L} \cdot \mathrm{L}^{-1}$ ), were more effective in controlling whitefly than were the elevated $\mathrm{CO}_{2}$ atmospheres $(25 \%$ or $50 \%)$. This is consistent with results of Butler et al. (1986) in which elevated $\mathrm{CO}_{2}$ levels, up to $200 \%$ ambient concentration, did not affect whitefly population in a cotton (Gossypium hirsutum L.) field. The susceptibility of whitefly to the reduced- $\mathrm{O}_{2}\left(<2 \mu \mathrm{L} \cdot \mathrm{L}^{-1}\right)$ atmosphere varies depending on the stage of development. The order from the least to most tolerant was adult $<$ larvae $<$ eggs $=$ pupae. The immature stages (eggs, larvae, and pupae) have been shown to be very resistant to pesticides and their responses to controlled atmospheres are similar.

Raising the treatment temperature significantly increased insecticidal effects of the CA. An increase from 20 to $30{ }^{\circ} \mathrm{C}$ significantly reduced the treatment time by one-half, regardless of the developmental stage of the whitefly. The insecticidal effects of controlled atmospheres have also been reported to be dependent on the temperature during treatment of Caribbean fruit fly (Benschoter, 1987), New Zealand thrips (Thrips obscuratus Crawford) (Potter et al., 1994), and western flower thrips (Frankliniella occidentalis Pergande) (M.S. Reid, personal communication). In addition, studies have shown that low $\left(0\right.$ to $\left.1{ }^{\circ} \mathrm{C}\right)$ (Potter et al., 1994; Seaton and Joyce, 1993) or high [hot water $\left(>45^{\circ} \mathrm{C}\right)$ dips or vapor heat $\left.\left(66^{\circ} \mathrm{C}\right)\right]$ temperature alone can be lethal to insects (Seaton and Joyce, 1993). However, the similarity in mortality rate of all stages of whitefly treated with air at 20 or $30{ }^{\circ} \mathrm{C}$ suggested that the shorter treatment time at higher temperature was due to the increased insecticidal effects of the low-O2 $\left(<2 \mu \mathrm{L} \cdot \mathrm{L}^{-1}\right)$ atmosphere and not to the temperature.

Many studies have been conducted which test either the physiological tolerance of a produce to CA conditions or the CA

Table 1. Effects of low- $\mathrm{O}_{2}\left(<2 \mu \mathrm{L} \cdot \mathrm{L}^{-1}\right)$ treatment on plant height and dry weight of leaves and stems of poinsettia. Rooted cuttings were exposed to air or a low- $\mathrm{O}_{2}$ atmosphere for $8 \mathrm{~h}$ at $20^{\circ} \mathrm{C}$ and were then grown in a greenhouse for 4 weeks. Data are means \pm SE of six replicate plants.

\begin{tabular}{|c|c|c|c|c|c|c|}
\hline \multirow[b]{2}{*}{ Cultivar } & \multicolumn{3}{|c|}{$\mathrm{Ht}(\mathrm{cm})$} & \multicolumn{3}{|c|}{ Dry wt $(\mathrm{g})$} \\
\hline & Control & $\begin{array}{c}\text { Low-O } \\
\left(<2 \mu \mathrm{L} \cdot \mathrm{L}^{-1}\right)\end{array}$ & Contrast $^{\mathrm{z}}$ & Control & $\begin{array}{c}\text { Low-O } \\
\left(<2 \mu \mathrm{L} \cdot \mathrm{L}^{-1}\right)\end{array}$ & Contrast \\
\hline$\overline{\mathrm{V}-17 \text { Angelica }}$ & $14.1 \pm 0.4$ & $11.4 \pm 1.0$ & $* *$ & $3.7 \pm 0.4$ & $2.4 \pm 0.3$ & $* *$ \\
\hline Celebrate II & $11.6 \pm 0.8$ & $9.9 \pm 0.8$ & NS & $0.4 \pm 0.3$ & $1.9 \pm 0.2$ & NS \\
\hline Freedom Red & $10.7 \pm 0.7$ & $9.9 \pm 0.7$ & NS & $2.9 \pm 0.3$ & $2.6 \pm 0.3$ & NS \\
\hline V-14 Glory & $11.1 \pm 0.5$ & $11.0 \pm 0.5$ & NS & $2.5 \pm 0.2$ & $2.2 \pm 0.2$ & NS \\
\hline Annette Hegg Red & $10.5 \pm 0.5$ & $9.5 \pm 0.5$ & NS & $2.0 \pm 0.2$ & $1.6 \pm 0.1$ & NS \\
\hline Lilo Red & $10.9 \pm 0.4$ & $10.7 \pm 0.6$ & NS & $2.5 \pm 0.2$ & $2.1 \pm 0.1$ & NS \\
\hline Pink Peppermint & $8.9 \pm 0.4$ & $10.0 \pm 0.4$ & NS & $2.0 \pm 0.2$ & $2.3 \pm 0.2$ & NS \\
\hline Red Sails & $10.7 \pm 0.8$ & $11.0 \pm 0.8$ & NS & $2.8 \pm 0.3$ & $2.3 \pm 0.3$ & NS \\
\hline Supjibi Red & $8.8 \pm 0.3$ & $6.5 \pm 0.5$ & $*$ & $2.4 \pm 0.1$ & $1.5 \pm 0.2$ & $*$ \\
\hline
\end{tabular}

$\overline{\mathrm{Ns},{ }^{*}, * * *}$ Nonsignificant or significant at $P=0.05$ or 0.01 , respectively. 
Table 2. Susceptibility of bracts of six cultivars of poinsettias to an $8 \mathrm{~h}$, low- $\mathrm{O}_{2}\left(<2 \mu \mathrm{L} \cdot \mathrm{L}^{-1} \mathrm{O}_{2}\right)$ treatment. The degree of phytotoxicity was estimated visually, at $10 \%$ increments, as the percentage of total bract area with discoloration. Data were collected $2 \mathrm{~d}$ after treatment and are means $\pm \mathrm{SE}$ of six replicate plants.

\begin{tabular}{lc}
\hline Cultivar & $\begin{array}{c}\text { Phytotoxicity } \\
(\%)^{\mathrm{z}}\end{array}$ \\
\hline Celebrate II & $0.1 \mathrm{c}^{\mathrm{y}}$ \\
Freedom Red & $7.0 \mathrm{~b}$ \\
V-14 Glory & $1.1 \mathrm{c}$ \\
Annette Hegg Red & $31.4 \mathrm{a}$ \\
Pink Peppermint & $0.3 \mathrm{c}$ \\
Supjibi & $4.1 \mathrm{c}$
\end{tabular}

zPercentage of area with symptoms of phytotoxicity.

yMean separation by Duncan's multiple range test, $P<0.05$.

conditions required for insect disinfestation. Few are a combination of the two and the variation in the individual studies make it difficult to compare conditions that would be tolerated by plants and lethal to insects (Ke and Kader, 1991). However, a study by Seaton and Joyce (1993) evaluated the physiological tolerance of three Australian cut flowers to various combinations of CA (high or low temperature, $\mathrm{O}_{2}$ and $\mathrm{CO}_{2}$ concentrations, and treatment time) as well as the $\mathrm{CA}$ treatment required for eradication of adult flour beetles (Tribolium confusum Koch.) and Mediterranean fruit fly larvae (Ceratitis capitata Wied.). They concluded that the tolerance level of the cut flowers to the CA treatment varies greatly among species. In addition, the duration of the CA treatment necessary to kill all insects was often longer than that tolerated by the cut flowers. In our study, the tolerance of plants to the CA treatment was dependent on the developmental stages. An 8-h low oxygen treatment $\left(<2 \mu \mathrm{L} \cdot \mathrm{L}^{-1}\right)$ at $20^{\circ} \mathrm{C}$, as required to affect the immature stages of whitefly, did not induce phytotoxicity or reduce growth and development of the rooted stem cuuttings of the various poinsettia cultivars that were tested. However, flowering poinsettias were very susceptible to the low $\mathrm{O}_{2}$ treatment $\left(<2 \mu \mathrm{L} \cdot \mathrm{L}^{-1}\right)$ resulting in discoloration of the leaves and petals or collapse of the leaf petiole within $2 \mathrm{~d}$ or, in severe cases, death of the plant. The tolerance of flowering poinsettias to low- $\mathrm{O}_{2}$ treatment $\left(<2 \mu \mathrm{L} \cdot \mathrm{L}^{-1}\right)$ was less than that required to achieve complete elimination of whitefly, thus limiting the practical application of low- $\mathrm{O}_{2}$ treatment as a quarantine treatment for this greenhouse crop.

\section{Literature Cited}

Akamine, E.K. and T. Goo. 1981. Controlled atmosphere storage of anthurium flowers. HortScience 16:206-207.

Benschoter, C.A. 1987. Effects of modified atmospheres and refrigeration temperatures on survival of eggs and larvae of the caribbean fruit fly in laboratory diet. J. Econ. Entomol. 80:1223-1225.

Butler, G.D., B.A. Kimball, and J.R. Mauney. 1986. Populations of Bemisia tabaci (Homoptera: Aleyrodidae) on cotton grown in open-top field chambers enriched with $\mathrm{CO}_{2}$. Environ. Entomol. 15:61-63.

Chu, C.L. 1992. Postharvest control of San Jose scale on apples by controlled atmosphere storage. Postharvest Biol. Technol. 1:361-369.

Davis, P.L. and W.G. Chace, Jr. 1969. Determination of alcohol in citrus juice by gas chromatographic analysis of headspace. HortScience 4:117119.

Hanan, J.J. 1967. Experiments with controlled atmosphere storage of carnations. Proc. Amer. Soc. Hort. Sci. 30:370-376.

Joyce, D.C. and M.S. Reid. 1985. Effect of pathogen-suppressing modified atmospheres on stored cut flowers, p. 185-198. In: S. Blankenship (ed.). Controlled atmospheres for storage and transport of perishable agricultural commodities. N.C. State Univ. Hort. Rpt. 126.

Ke, D. and A.A. Kader. 1991. Potential of controlled atmospheres for postharvest insect disinfestation of fruits and vegetables. Postharvest News Info. 3:31-37.

Norman, S.M. and C.C. Craft. 1971. Production of ethanol and acetaldehyde on postharvest quality of mechanically harvested strawberries for processing. J. Amer. Soc. Hort. Sci. 104:242-264.

Parsons, C.S., S. Asen, and N.W. Stuart. 1967. Controlled atmosphere storage of daffodil flowers. Proc. Amer. Soc. Hort. Sci: 90:506-514.

Pesis, E. and I. Avissar. 1989. The postharvest quality of orange fruits as affected by pre-storage treatments with acetaldehyde vapor or anaerobic conditions. J. Hort. Sci. 64:107-113.

Potter, M.A., A. Carpenter, A. Stocker, and S. Wright. 1994. Controlled atmospheres for the postharvest disinfestation of Thrips obscuratus (Thysanoptera: Thripidae). J. Econ. Entomol. 87:1251-1255.

Sanderson, J. and G. Ferrentino. 1989. Whitefly biology and management in the greenhouse. Hort. News. Nov. (1-4).

SAS Institute, Inc. 1990. SAS/STAT user's guide. 4th ed. SAS Inst., Cary, N.C.

Seaton, K.A. and D.C. Joyce. 1993. Effects of low temperature and elevated $\mathrm{CO}_{2}$ treatments and of heat treatments for insect disinfestation on some native Australian cut flowers. Scientia Hort. 56:119-133.

Soderstrom, E.L. and D.G. Brandl. 1987. Controlled atmospheres for postharvest control of codling moth on fresh tree fruits. California Tree Fruit Agreement, Sacramento. CTFA 1986 Res. Rpt.

Thornton, N.C. 1930. The use of carbon dioxide for prolonging the life of cut flowers, with special reference to roses. Amer. J. Bot. 17:614-626. 